2. Jaiswal S, Fontanillas P, Flannick J, et al. Age-related clonal hematopoiesis associated with adverse outcomes. N Engl J Med 2014;371:2488-98.

3. Lawrence MS, Stojanov P, Mermel CH, et al. Discovery and saturation analysis of cancer genes across 21 tumour types. Nature 2014;505:495-501.
4. Shlush LI, Zandi S, Mitchell A, et al. Identification of preleukaemic haematopoietic stem cells in acute leukaemia. Nature 2014;506:328-33.

DOI: 10.1056/NEJMc1500684

\title{
Cytisine versus Nicotine for Smoking Cessation
}

TO THE EDITOR: Walker et al. (Dec. 18 issue) ${ }^{1}$ describe the use of cytisine, as compared with nicotine, for smoking cessation. Although cytisine is perceived as a novelty in the West, it has been used in daily medical practice in Poland for more than 50 years. $^{2}$ In 1976, the first English-language study on the use of cytisine in Poland was published, based on the observations of $1968 \mathrm{pa}-$ tients. ${ }^{3}$ Cytisine is currently undergoing a renaissance in Poland. Two Polish studies - a cohort study conducted in 2003 through $2005^{4}$ and a randomized, controlled trial conducted in 2006 through $2010^{5}$ - showed the safety and effec-

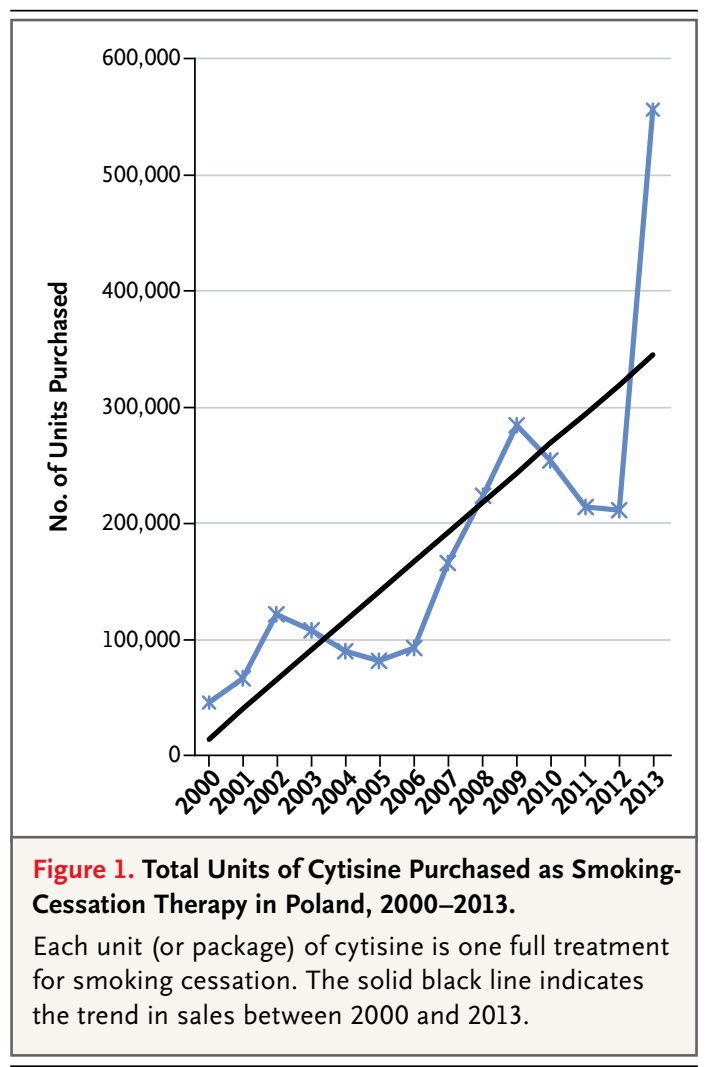

tiveness of the drug. In 2012, a Polish generic drug company broke the monopoly by introducing a new cytisine product, Desmoxan. Cytisine is very inexpensive in Poland, costing under $\$ 20$ for full treatment. Its consumption has grown by factor of 10 since 2000 (Fig. 1). In 2013 alone, after cytisine became available over the counter and was heavily advertised, sales of the drug doubled. The use of cytisine is widespread, and it is considered to be safe by medical professionals and consumers. It seems that the use of cytisine is a major factor behind the decline in smoking in Poland - in the past 2 years, 500,000 smokers have quit. ${ }^{6}$ It is certainly desirable for this success to be replicated elsewhere.

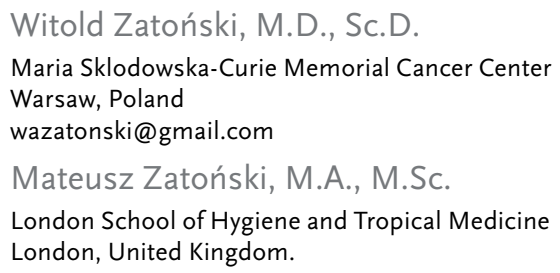

No potential conflict of interest relevant to this letter was reported.

1. Walker N, Howe C, Glover M, et al. Cytisine versus nicotine for smoking cessation. N Engl J Med 2014;371:2353-62.

2. Tutka P, Zatonski W. Cytisine for the treatment of nicotine addiction: from a molecule to therapeutic efficacy. Pharmacol Rep 2006;58:777-98.

3. Granatowicz J. Smoking cessation through the use of cytisine and other chemotherapy. World Smoking Health 1976;1:811.

4. Zatoński W, Cedzynska M, Tutka P, West R. An uncontrolled trial of cytisine (Tabex) for smoking cessation. Tob Control 2006;15:481-4.

5. West R, Zatoński W, Cedzynska M, et al. Placebo-controlled trial of cytisine for smoking cessation. $\mathrm{N}$ Engl $\mathrm{J}$ Med 2011;365:1193-200.

6. Zatonski W, Sulkowska U, Przewozniak K, Zatonski M. Malignant cancer epidemiology in Poland. In: Potrykowska A, Strzelecki Z, Szymborski J, Witkowski J, eds. Cancer incidence and mortality versus the demographic situation in Poland. Warsaw, Poland: Governmental Population Council, 2014:30-49. (In Polish.)

DOI: 10.1056/NEJMc1500342 